\title{
Study on Learning Organizations in Makassar City Government
}

\author{
Badu Ahmad ${ }^{1}$ \\ ${ }^{1}$ Lecturer in the Department of Administration, State Administration Study Program, Faculty \\ of Social and Political Sciences, Hasanuddin University Makassar, South Sulawesi, Indonesia \\ Received: November 11, 2021 \\ Received in Revised: December 7, 2021 \\ Accepted: December 15, 2021
}

\begin{abstract}
Badu Ahmad, Study on learning organtzation in Local Government Makassar. The aims of this research was analyze the implementation of learning organization, factors which is support bulding learning bureaucracy as an effort to follow the changing environment and demand of society. This research applied and quantitative and qualitative technique which is used the stratified random sampling Meanwehile, to cathce the data, informant to be used namely the leaders in the body of local government in Makassar. Analysis of data is descriptive quantitative and also qualitative with frequency distribution technique. The research result showed that there are good tend to apply learning bureaucracy which indicated of the apparatus want to learn continually from experience, fault, and also they can catch new knowledge and working system and other aspect related to societies" demand. The other found that the commitment factors and working environment in a good sense in building the learning bureaucracy in local government of Makassar. Aspects that related cultural values also determined applying the learning bureucracy, such as siri' (self-respect), sipukatau sipakalebbi' (respect each other), sipakario (motivation). Those are urgently required in building self capacty simultaneously in local burraucracy of Makassar.
\end{abstract}

Keywords: Organization, Learning, Government

\section{Introduction}

Change or renewal of something, theoretically, is actually a natural thing for anyone, even it is a part of human life. Thus being responsive to changes in the bureaucratic environment is a necessity if you want a better life as part of realizing the demands for good governance.

Changes in the government bureaucratic environment in Indonesia began to be felt since the birth of the Reformation Order in 1998, since then it has also given rise to the idea of transforming bureaucratic culture, especially the culture of wanting to learn in the midst of the wind of renewal that is being and continues to be blown to this day which is very important even though it is western.

Changes that are hard dimensions include the dimensions of government institutions and management, government administration systems and procedures, the use of technology, or technical managerial problems in public services, but neglecting the soft dimension, namely bureaucratic culture, especially the culture of wanting to learn the core dimensions of our state administration practice. (Terilestari, 2007). Is the bureaucracy thirsty for change (Change).

The answer will depend on the problem of the character of the bureaucracy that it bears, namely the culture of wanting to learn, although it is not the only one.

Transforming the way the bureaucracy works is not an easy matter, which can happen in the blink of an eye, but requires a long and continuous process and requires a strong commitment from every bureaucratic person, especially from the top leadership to the lowest level. Why? Because of changes in the way the bureaucracy works, especially those who want to learn about

Copyright $\odot$ 2021, Journal of Asian Multicultural Research for Social Sciences Study, Under the license CC BY-SA 4.0 
changes in values, habits, attitudes, norms, mindsets (mindset), even belief in each personal apparatus which has actually been formally formed since the era of the (pre-colonial) imperialism set foot in this country., which is known as a patrimonial and or feudal bureaucratic culture that expresses traditional values (Riggs, 1995: 333). From a cultural perspective, the Indonesian bureaucracy despite showing its modern structure

Changes In accordance with the meaning of Law 32 of 2004 concerning regional autonomy as an effort to change the mindset or mindset from the concept of pangre-praja (ruler) to civil servants (servants of the state) it turns out that abuse still carries patrimonial or paternalistic values, for example the occurrence of a work pattern that patron/client in bureaucratic life (triletari, EW 2007).

The changes or reforms of the bureaucracy in Indonesia in 1998 that appeared to be only reforms at the instrumental level, namely reforms related to statutory instruments, ranging from the Constitution to lower statutory instruments. Meanwhile, those relating to the workings of the bureaucracy do not seem to have experienced it (Mustofadidjaja, 2003).

Therefore, based on some of these objective facts, the government bureaucracy, especially in the Makassar City Government Environment as a government administrator, development agent, making regulations, public services and community empowerment must make changes in the learning dimension.

Toffler (1985), Trilling and Hood (1999) suggest that organizations are required to always change themselves through learning in order to be able to increase their capacity, because they rely on quality, creative, critical, and innovative human capital. The key to reforming the way the bureaucracy works towards a learning organization lies in each individual or individual and the commitment of the leadership within the government bureaucracy. Does he want to change and continue to learn from his mistakes and weaknesses through a five-discipline approach in learning organizations so that they are qualified, creative, critical, and innovative which are useful for the bureaucracy internally and society externally (Triletari, E. W. 2007).

\section{Learning Organization}

The new era of tomorrow, will present a new way of dealing with it. Successful organizations are organizations that first master new ways and anticipate various obstacles and do something different (Sedarmayanti, 2000:16). Organizations need a clear point of view, about where they are going, a clear vision of where the organization's members want to be tomorrow and a vision of the direction they must take today in order to achieve their goals successfully (Kouzes and Posner, 1997: 100). . Without this clarity, members of the organization will be racing into the future without direction, and this means missing opportunities and mired in various crises, while other organizations race their fate. This is reaffirmed by (Kouzes and Posner, 1997:102) that the vision can only be achieved, if all members of the organization have the same understanding, then supported by actions in accordance with the vision and mission of the organization.

Organizational leaders must have imagination and be able to draw mental processes to create the future of the organization in accordance with a mutually agreed vision. This is also related to the view of Gibson (1990:xxxix) that in the 21st century the winners are those who are adapting to change, constantly re-identifying their products, creating innovations, exploring new fields, trying to find productive and productive rules. against the status quo. It is also said by (Kouzes and Posner, 2011: 184, 1997b: 129) that to create a vision and purpose that is meaningful, has a distinctive purpose, and will give an edge going forward, if it displays 21st century organizational leaders, namely leaders who look far into the future. future, observing competition and the demands of the community environment, new opportunities, and avoiding 
crises (Sedarmayanti, 2000:17). According to Gibson (1990: xii) organizational leaders who love change, will make changes in their organizations, and have deep vision, passion and aspirations going forward and determine in the future because they are innovative and interesting.

In the systems paradigm, the question is the mechanistic system and the organic system. Mechanistic systems see a formal organizational structure and tend to be hierarchical, with highly centralized control, an overemphasis on specialization as it tries to increase efficiency. Organizations are seen as closed to their environment. If this system is adopted by an organization, it means that there is no opportunity to apply discipline within the learning organization. While the organic system is more concerned with people not tasks, reduces hierarchies, flexible group structure, prioritizes mutually agreed values and norms, emphasizes self-control, adapts to each other, has high adaptability, is applied to dynamic conditions, has an innate focus high responsiveness, and responsive to rapid changes by making policies and actions quickly (Morgan, 1986). Organizations that implement an organic system and this will simplify and speed up the implementation of learning organizations. However, the collaboration paradigm directs its attention to reality and needs (responsiveness), so that in the paradigm emerges the basic principle of learning organization in the postmodern paradigm is continuous learning in accordance with the development and demands of the internal and external environment (Jo Hat, 1997:366).

Conceptually and theoretically, Senge (1995) suggests that an organization that is able to learn and react quickly to changing environmental conditions can be said to be a learning organization. While practically organizational learning is an organization that is able to carry out the learning process faster. This organization is described by Marquardt (1996). as an organization that continuously transforms itself and is able to manage knowledge, utilize technology, "empower" people, and expand learning to be able to adapt better so as to be successful in environmental changes.

Learning in organizations means to be able to adapt better so that they are successful in continuous change, and change that experience by all members of the organization and is relevant to its main goals (Weick, 1969). While Senge emphasizes organizational members (humans) constantly expanding their capacity, new thinking patterns develop, collective aspirations can take place freely, and individuals are constantly aging. environment. Continuous testing of knowledge that can be accessed becomes a "learning" organization under conditions in which to create the results they want. By "learning" expansion and learning, as well as learning together/teams.

Senge (1994) popularized learning organization in his book "The Fifth Discipline" explaining that learning organization aims where people continuously expand their capacity to create the results they really want, where new patterns of thinking as well as expanded thinking patterns are nurtured, where collective aspirations are set free, and where people as experts continually learn, and how to learn together.

Furthermore, Senge (2002: 59), Haines, (1998) suggested that the discipline of personal skills, mental models, and systems thinking will help us to productively examine and change the way we think. Changing the way employees interact means redesigning, not only the formal structures of the organization, but also the hard-to-see patterns of interaction between people and processes. While the disciplines of shared vision, systems thinking, and team learning are specifically aimed at transforming interactions.

For this reason, Guns (1996 2) suggests that basically all organizations learn, but not all organizations are based on learning. Many organizations are performance based, focusing on 
the present so that the financial side is seen as better in the short term, but these ways are currently considered irrelevant, because the performance base is less long term. The advantage of a learning-based organization is that it focuses more on trying to do its job better, and views learning as the best way to improve long-term performance.

The definition put forward by experts shows that a learning organization is an organization that is able to continuously develop its ability to create a better future." The essence of a learning organization is that if an organization wants a change and continues to exist, then the people in The organization must have a culture of being willing to learn continuously and continuously by following changes and developments in the environment (environment adaptable).

Senge, (1990,), Marquardt (1996) said that to examine learning organizations, one of the dimensions that must be considered is Critical organizational learning skills; These skills include 6 (six) discipline factors; among others: (a) Shared vision, which describes the shared perspectives of organizational members including their understanding of the organization's mission and goals, (b) Mental Models which basically include values, beliefs, attitudes, and assumptions that shape a person's perspective. Structures, cultural experiences, belief systems support mental models that provide guidance to a person and act as a filter during the decision being made. (c) Team Learning (team learning) helps the process of communication and cooperation, leading to synergy and mutual respect between them. Team members broaden their horizons (d) Individuals who are experts in their fields (personal mastery) are an important prerequisite as part of a very strategic organizational asset. Individual expertise and skills can be obtained from formal education, and work experience. (e) Systems thinking includes testing and reflecting on all aspects of organizational life such as mission, strategy, structure, culture and managerial practice. Understanding and action is more focused on integrating different sections or divisions towards maximizing strengths, minimizing weaknesses, and improving the entire operationalization of the organization, (f) Dialogue, where organizational members have the freedom to channel innovation, creativity, ideas, which are considered capable of doing something. something that is best for himself, the team, and the organization. Openness of the leadership is the main requirement, and the leadership views the staff as friends, coworkers or partnerships (Katzenbach, and Smith, 1993).

The amalgamation of the six disciplines of opinion views that the foundation must be strengthened to make a learning organization. Marquartd (1996), Senge (1999), argue that towards a learning organization, several supporting factors are needed, namely: work environment, organizational operationalization, communication, commitment, motivation and learning strategies, bureaucratic simplification, empowerment, sustainable, adaptive, holistic improvement .

\section{Methods}

The research uses quantitative and qualitative methods (mixed method). Variables include: shared vision, personal expertise (individual mastery), mental models (mental models), team learning (team learning), and systems thinking (system thinking). ), with the selected indicator. Then the indicator is elaborated in a questionnaire with ordinal data type.

Data were collected through 165 respondents consisting of 50 groups II, 100 groups III, and 15 groups IV. While the informants are assistants, heads of sections, and related sub-sections.

The sampling technique from a population of 236 civil servants used stratified random sampling of $30.3 \%$ Gol. II, $60.6 \%$ Goals. III, 9.1\% Goal. IV, while the informants were carried out by purposive sampling, namely informants who could provide data and information related to the problems studied. The data extracted from the respondents were analyzed by statistical analysis 
(percentage). Meanwhile, the results of the interviews enrich the results of the quantitative analysis so that the conclusions drawn are more objective.

\section{Results and Discussion}

Portrait of the Application of the Five Disciplines in Learning Organizations in Makassar City Government. The prospect of building a learning bureaucracy in the Makassar City Government is quite promising because the commitment of the leaders and their subordinates is quite good in responding to changes in the internal and external environment, especially the demands of society which are increasingly complex. Makassar City government officials make the experience. shortcomings, weaknesses and mistakes in the past become an excellent source of learning towards better things in the future.

The Makassar City Government's vision is "Makassar as a City of Maritime, Commerce, Education, Dignity and Humanity" as an element of commitment to communication about the Makassar City Government's vision to all organizational components so that they understand and work according to the main tasks and functions as an elaboration of the vision and mission.

A portrait of the implementation of shared vision discipline in the Makassar City Government Environment in the high category, as illustrated in the table below:

Table 1. Implementation of the Shared Vision

\begin{tabular}{|l|l|l|l|l|l|}
\hline Level & $\begin{array}{l}\text { Socialization } \\
\text { of Vision }\end{array}$ & $\begin{array}{l}\text { Conformity of } \\
\text { vision and Auth }\end{array}$ & $\begin{array}{l}\text { Prediction of the } \\
\text { goal of the next 5 } \\
\text { years }\end{array}$ & $\begin{array}{l}\text { Achieve the } \\
\text { current goal }\end{array}$ & $\begin{array}{l}\text { Relationship } \\
\text { with target }\end{array}$ \\
\hline High & $91,5 \%$ & $88 \%$ & $72,73 \%$ & $92,8 \%$ & $97 \%$ \\
\hline Low & $8,4 \%$ & $12 \%$ & $27,27 \%$ & $7,2 \%$ & $3 \%$ \\
\hline
\end{tabular}

Prospek untuk membangun birokrasi pembelajar di Lingkungan Pemerintah Kota Makassar, sangat memungkinkan karena pada umumnya unsur pimpinan bersama staf memiliki visi bersama tentang arah, sasaran dan tujuan yang ingin di capai ke depan. Pencapaian visi dapat terealisasikan karena didukung oleh tupokis yang dapat berjalan baik. Tingkat capaian sasaran yang cukup tinggi saat ini, menunjukkan adanya komitmen para staf untuk memberikan Pelayanan dan mensejahterakan masyarakatnya.

Optimalisasi capaian sasaran sesuai visi Pemerintah Kota Makassar karena didukung sumber daya aparatur yang memiliki keahlian pribadi yang cukup tinggi, seperti pada tabel 2:

Table 2. Application of Personal Expertise (Individual Mastery)

\begin{tabular}{|l|l|l|l|l|l|l|l|l|}
\hline Level & $\begin{array}{l}\text { Training } \\
\text { in skills }\end{array}$ & $\begin{array}{l}\text { Expertise } \\
\text { with } \\
\text { work }\end{array}$ & $\begin{array}{l}\text { Speed of } \\
\text { improvement }\end{array}$ & $\begin{array}{l}\text { Experience } \\
\text { with } \\
\text { expertise }\end{array}$ & $\begin{array}{l}\text { Spirit of } \\
\text { learning }\end{array}$ & $\begin{array}{l}\text { Appreciation } \\
\text { for expertise }\end{array}$ & $\begin{array}{l}\text { Expertise } \\
\text { with } \\
\text { vision } \\
\text { mistakes } \\
\text { of } \\
\text { learning } \\
\text { facilities }\end{array}$ \\
\hline High & $82,4 \%$ & $90,3 \%$ & $90,1 \%$ & $92,8 \%$ & $88,5 \%$ & $91,5 \%$ & $86,6 \%$ & $94,5 \%$ \\
\hline Low & $17,6 \%$ & $9,7 \%$ & $9,9 \%$ & $7,2 \%$ & $11,5 \%$ & $8,5 \%$ & $13,4 \%$ & $15,5 \%$ \\
\hline
\end{tabular}

Personal vision will form personal expertise (individual mastery). so that members of the organization have the same vision of the direction and goals of the Makassar City Government. Individual expertise is acquired through training, education and training. These skills can be applied properly because they are relevant to the work at hand. Because there is a match between expertise and the work at hand, the morale is quite high. To maintain and improve individual skills, various forms of awards are needed in the form of financial and non-financial. 
The level of mastery / individual expertise is quite high, so that if you make a work error, it is immediately corrected, even asking for help from colleagues to overcome the problems encountered. The application of individual expertise in an organization can only be optimal if it is based on the mental readiness of the apparatus in dealing with various changes. The application of the discipline of mental models in the Makassar City Government Environment is as shown in the table in table 3

In general, the application of mental models of the Makassar City government apparatus is quite high. This condition is seen in general, employees can work well in accordance with their main duties and functions.

Table 3. Application of MentalModels (MentalModels)

\begin{tabular}{|l|l|l|l|l|l|l|l|}
\hline Level & $\begin{array}{l}\text { Attitude } \\
\text { towards } \\
\text { work }\end{array}$ & $\begin{array}{l}\text { Honesty } \\
\text { and } \\
\text { discipline }\end{array}$ & $\begin{array}{l}\text { Use of New } \\
\text { Technology }\end{array}$ & $\begin{array}{l}\text { The desire } \\
\text { to make a } \\
\text { change }\end{array}$ & $\begin{array}{l}\text { Attitudes } \\
\text { towards } \\
\text { new } \\
\text { working } \\
\text { methods }\end{array}$ & $\begin{array}{l}\text { Readiness } \\
\text { for new } \\
\text { working } \\
\text { methods }\end{array}$ & $\begin{array}{l}\text { Priority } \\
\text { work }\end{array}$ \\
\hline High & $97 \%$ & $92,12 \%$ & $84,8 \%$ & $97,5 \%$ & $86,2 \%$ & $81,2 \%$ & $93,3 \%$ \\
\hline Low & $3 \%$ & $7,8 \%$ & $15,2 \%$ & $2,5 \%$ & $13,3 \%$ & $8,8 \%$ & $6,7 \%$ \\
\hline
\end{tabular}

Demonstrates a high level of discipline and honesty, so that it strongly supports the creation of good governance (good governance), clean government (good government), and good service. In general, the apparatus is willing to adapt to the use of new technology, new work systems, and various other policy changes. Everyone, this can be realized the importance of changing the mental from reactive or proactive, because they are involved in determining the priority scale of activities according to their main function. Every success achieved by the organization is due to a fairly good team work, so that any shortcomings or weaknesses that a person has can be overcome by existence. The conditions for the application of team learning discipline in the Makassar city government are as shown in table 4 below

Table 4. Implementation of Team Learning

\begin{tabular}{|l|l|l|l|l|l|l|}
\hline Level & $\begin{array}{l}\text { Involved in } \\
\text { the team }\end{array}$ & $\begin{array}{l}\text { Difficulty is } \\
\text { solved } \\
\text { through } \\
\text { cooperation }\end{array}$ & $\begin{array}{l}\text { Success } \\
\text { between } \\
\text { work units }\end{array}$ & $\begin{array}{l}\text { Discussion } \\
\text { and } \\
\text { discussion } \\
\text { as a means } \\
\text { of learning }\end{array}$ & $\begin{array}{l}\text { Discussion } \\
\text { and vision } \\
\text { dialogue }\end{array}$ & $\begin{array}{l}\text { Maintain } \\
\text { the spirit of } \\
\text { teamwork }\end{array}$ \\
\hline High & $96,3 \%$ & $95,2 \%$ & $92,1 \%$ & $86 \%$ & $80 \%$ & $90,3 \%$ \\
\hline Low & $9,7 \%$ & $4,8 \%$ & $7,9 \%$ & $14 \%$ & $20 \%$ & $9,7 \%$ \\
\hline
\end{tabular}

The success rate of the organization is quite high because Makassar city government officials are aware of their role in the team. One of the benefits obtained by the apparatus who are in the team is that they can overcome the difficulties they face, and learn from the strengths of others. In addition, the success rate of each work unit is quite high because it creates a conducive cooperation. The transformation of knowledge through dialogue and discussion on new matters, including strategies for achieving the vision, is quite well done so that all members in the group have the same understanding so that the same actions are created, so that harmonization and team spirit are realized.

The application of the four disciplines above must be based on systems thinking, because the four disciplines cannot work alone, but must work together. For each apparatus, they must be able to think systems, namely looking at the relationship between all components or elements holistically to build a learning bureaucracy in the Makassar City Government Environment. The conditions for the application of systems thinking are as in table 5. 
Table 5. System thinking

\begin{tabular}{|l|l|l|l|l|l|l|}
\hline Level & $\begin{array}{l}\text { Understand } \\
\text { mechanisms } \\
\text { and } \\
\text { procedures }\end{array}$ & $\begin{array}{l}\text { Synergy } \\
\text { between } \\
\text { work units }\end{array}$ & $\begin{array}{l}\text { Work unit } \\
\text { responsibilities }\end{array}$ & $\begin{array}{l}\text { Structure to } \\
\text { creativity } \\
\text { and } \\
\text { innovation }\end{array}$ & $\begin{array}{l}\text { Works not } \\
\text { exactly the } \\
\text { same } \\
\text { system }\end{array}$ & $\begin{array}{l}\text { Ability to } \\
\text { adapt to } \\
\text { system } \\
\text { thinking }\end{array}$ \\
\hline High & $87,3 \%$ & $89,1 \%$ & $81,8 \%$ & $60,2 \%$ & $55,1 \%$ & $83,1 \%$ \\
\hline Low & $12,7 \%$ & $10,9 \%$ & $8,2 \%$ & $39,8 \%$ & $44,9 \%$ & $16,9 \%$ \\
\hline
\end{tabular}

Table 5 shows that the prospects for implementing learning organizations in the government are quite good. This is because in general employees can work based on mechanisms and procedures. Even though the mechanisms and procedures that have been implemented so far, can hinder the creativity and innovation of the apparatus in working and produce products that are more attractive and give satisfaction to the community. Thus, many apparatus work differently as required by the system (rules) such as work form designs, service systems and others. However, the level of responsibility of the apparatus for the main tasks of the work unit is quite high, so that the synergy is still well maintained. The level of the apparatus' ability to adapt (adapt) to any system changes is quite high, so that there is no difficulty for the leadership to monitor or evaluate the work unit.

The prospect of building a learning organization in the Makassar City government, in addition to using the five-disciplinary approach in learning organizations according to Senge (1996), should also pay attention to local cultural values, namely Siri' values as one of the BugisMakassar cultural values, which is very decisive in improving work ethic of government officials in Makassar City (1975), Rahim (1992). The value of siri' motivates a person to be macca (smart, skilled), malempu (honest), assitinajang (obedient to principles), assigettengeng (determination), reso' (business), attitude or/sipakasiri (mutual respect/maintaining shame), sipakario ( zest for life/joy). Theoretically, the spirit of the government apparatus in Makassar City Environment is to increase capacity, the basic attitude of an apparatus regarding selfability is revealed that siri' is a source of motivation in learning so that work performance can improve continuously. Rahim (1992) asserts that employees who are lazy and depend on the compassion of others are considered low-grade siri'na, because the apparatus must study, be diligent, excel in work so as not to fall into jealousy'.

\section{Conclusion}

The prospect of implementing learning organizations in the Makassar City government environment for continuous learning to increase its capacity in accordance with community demands or environmental changes is quite good. This prospect is supported by a strong commitment, adequate resources and a conducive working environment. In addition, it is necessary to plan, develop, develop human resources for personnel based on a merit system as mandated by Law 43 of 1999. An objective and fair system of reward and punishment. Simplification of the bureaucratic structure to build creativity and innovation of the apparatus. Build awareness of the government apparatus for religious approaches and siri' cultural values, attitudes or attitudes to study and work sincerely and responsibly in accordance with their functions as servants of the State and servants of the community. From the various forces to build learning organizations within the Makassar City Government, it turns out that there are still government officials who are not ready individually, mentally to apply the five disciplines in learning organizations.

\section{References}

Gibson, J. L., Ivancevich, J. M., \& Donnelly, J. H. (1996). Organisasi, Perilaku, Struktur dan Proses, Edisi 8. Terjemahan, Penerbit Binarupa Aksara, Jakarta. 
Guns, B. (1996). The learning organization: Gain and sustain the competitive edge. Pfeiffer, San Diego, CA.

Jo Hat, Mary. (1997). Organization Theory; Modern Symbolic, and Postmodern Perspectives, Oxford University Press. New York.

Katzenbach R. J., Smith K. D. (1993). The Wisdom of Teams (Kemampuan Tim), Penerjemah: Agus Maulana, Professional Books. Jakarta.

Kouzes J.M \& Posner B.Z. (1997). The Leadership Challenge, Jossey-Bass, A Wiley Company, San Fransisco.

Kouzes, J. M., \& Posner, B. Z. (2011). Credibility: How leaders gain and lose it, why people demand it (Vol. 203). John Wiley \& Sons.

Marguardt, M.J, (1996)., The Learning Organization; a System Approach to Quantum Improvement and Global Success. McGraw-Hill.

Marguardt, M.J. (1996), Building the learning organization. A system approach to quantum improvement and global success. McGraw-Hill. New York.

Morgan, Gareth. (1986). Images of Organization, York University, Toronto.

Mustofadidjaja, A.R. (2003). Sistem Administrasi Negara Kesatuan Republik Indonesia, LAN , Jakarta.

Riggs, F.W. (1985). Administrasi Negara Berkembang: Teori Masyarakat Psmatis, (Termejahan), Rajawali, Jakarta.

Sedarmayanti, (2000), Restrukturisasi dan Pemberdayaan Organisasi Untuk Menghadapi Dinamika Perubahan Lingkungan, Mandar Maju, Bandung.

Senge, P. M. (1990). The Fifth Discipline. The art and practice of learning organization. Double Day/Currency. New York.

Senge, P. M. (2014). The fifth discipline fieldbook: Strategies and tools for building a learning organization. Currency.

Senge, P., Robert Charlotte, Kleniner Art; Smith Bryan, Roth George, Ross Richard. (1999). The Dance of Change; The Challenge of Sustaining Momentum in Learning Organization, Doubleday, London.

Senge, Peter, Kofman Fred, Kanter; Mos Elisabeth. (1995). Learning organization; Developing Cultures for Tomorrow Workplace, Productivity Press.

Toffler, Alvin. (1985). The Adaptif Corporation, McGraw-Hall, New York.

Trilestari, W.E. (2007). The Learning Organization Sebagai Pendekatan Transformasi budaya Birokrasi, LAN, Bandung.

Weick, Karl. (1969). The Social Psychology of Organizing, Reading, Mass: Addison: Wesley. 